Abstract P242 Table 1 Summary statistics from the fitted model and comparisons between chronic cough patients and healthy volunteers are presented below as adjusted geometric means and the pairwise differences ratios of the adjusted means

\begin{tabular}{|c|c|c|c|c|c|c|}
\hline \multicolumn{7}{|c|}{$C_{5}$ Capsaicin Concentration - Adjusted Means and Difference Ratios between Subject Types } \\
\hline & \multirow{2}{*}{$\begin{array}{l}\text { Chronic Cough Patients }(\mathrm{N}=10) \\
\text { Adjusted Geometric Mean }(\mu \mathrm{M})\end{array}$} & \multirow{2}{*}{$\begin{array}{l}\text { Healthy Volunteers }(\mathrm{N}=12) \\
\text { Adjusted Geometric Mean }(\mu \mathrm{M})\end{array}$} & \multicolumn{4}{|c|}{ Chronic Cough Patients vs. Healthy Volunteers } \\
\hline & & & Geom & Ratio with $95 \% \mathrm{Cl}$ & & pairwise $p$-value \\
\hline Overall & 35.2 & 77.4 & 0.46 & $0.20,1.09$ & 0.078 & \\
\hline \multicolumn{7}{|c|}{ By Infusion Type } \\
\hline Acid & 29.5 & 83.8 & 0.36 & $0.15,0.88$ & 0.025 & \\
\hline Saline & 41.8 & 71.4 & 0.42 & $0.20,0.87$ & 0.019 & \\
\hline \multicolumn{7}{|c|}{ By Infusion Type and Order } \\
\hline \multicolumn{7}{|l|}{ Acid } \\
\hline Acid-Saline & 20.0 & 114.3 & - & - & - & \\
\hline Saline-Acid & 43.5 & 61.3 & - & - & - & \\
\hline $\mathrm{p}$-value & 0.039 & 0.367 & - & - & $\cdot$ & \\
\hline \multicolumn{7}{|l|}{ Saline } \\
\hline Acid-Saline & 30.8 & 105.4 & - & - & - & \\
\hline Saline-Acid & 56.7 & 48.3 & - & - & - & \\
\hline$p$-value & 0.245 & 0.167 & - & - & - & \\
\hline
\end{tabular}

\section{P243 ASSESSING THE EFFECT OF PH ON CITRIC ACID COUGH CHALLENGES IN CHRONIC COUGH PATIENTS AND HEALTHY VOLUNTEERS}

Z Rai, H Fowles, J Howard, A Morice. Hull and East Yorkshire NHS Foundation Trust, Hull, UK

\subsection{6/thoraxjnl-2015-207770.379}

Introduction Citric acid has been used for over 6 decades in cough challenge studies, however despite this, the mechanism of its tussive effect is still not fully understood. We assessed the cough response to citric acid solutions, at different levels of acidity $(\mathrm{pH})$ to determine what role this plays in the induction of cough. Healthy volunteers and chronic cough patients were compared.

Methods 20 chronic cough patients and 20 healthy volunteers were recruited and underwent three cough challenges at $48 \mathrm{~h}$ apart. Each visit involved 5 repeated inhalations of a $300 \mathrm{mM}$ citric acid solution. Whilst the concentration of the citrate cation was kept constant, the $\mathrm{pH}$ was varied by titration with sodium hydroxide, to achieve $\mathrm{pH} \mathrm{3,5}$ and 6 . These represent the Pka values of the individual acid moieties within citric acid. The total number of coughs elicited per study day was recorded.

\section{Mean Number of Coughs in Chronic Coughers} and Healthy Volunteers

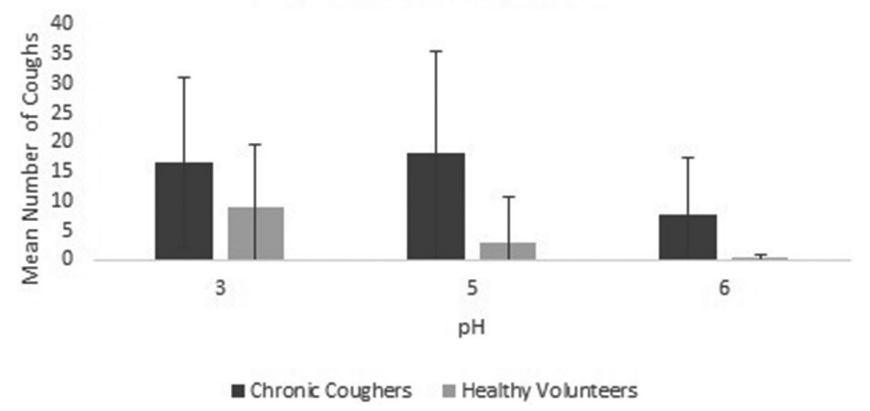

Abstract P243 Figure 1
Results Participants were gender matched, each group consisting 12 females Two participants withdrew and were not included in the analysis. In healthy volunteers, $60 \%$ of people coughed at $\mathrm{pH} 3$ (average coughs 9), 30\% of people coughed at pH5 (average coughs 3 ), and $10 \%$ of people coughed at $\mathrm{pH} 6$ (average coughs 0 ). In contrast, $74 \%$ of chronic coughers coughed at $\mathrm{pH} 3$ (average coughs 16), 89\% coughed at $\mathrm{pH} 5$ (average coughs 18) and $63 \%$ coughed at $\mathrm{pH} 6$ (average coughs 7 ). Thus there was a clear dose response to decreasing $\mathrm{pH}$ in healthy volunteers but not in chronic cough patients. The standard deviation of cough challenge on an individual day was determined to explore the variability of response to inhalation challenge. At $\mathrm{pH} 3 \mathrm{CC}$ vs $\mathrm{HV}$ was $\mathrm{x}$ vs $\mathrm{y}$, at $\mathrm{pH} 5 \times 1$ vs $\mathrm{y} 1$ and at $\mathrm{pH} 6 \times 2$ vs $\mathrm{y} 2(\mathrm{p}>0.01)$.

Discussion As we have previously reported, chronic cough patients are hypersensitive to citric acid challenge. However the response to individual challenge is much more variable than in $\mathrm{HV}$, suggesting the cough reflex circuitry in these patients is 'unstable'. This was particularly shown at higher $\mathrm{pH}$ where cough was virtually abolished in healthy volunteers but not chronic cough patients. It has been widely suggested that cough hypersensitivity resides in up regulation and interplay of different peripheral receptors. That a single stimulus increases the variability of response in a pathological state suggests that hypersensitivity to citric acid resides in a complex central rather than peripheral mechanism.

\section{Asthma quality improvement}

\section{P244 \\ THE IMPACT OF "SEVEN DAY WORKING" ON RESPIRATORY INPATIENT ACTIVITY AT ST HELENS AND KNOWSLEY NHS TRUST. - "THE SLOW DRIFT MODEL"}

S Twite, P Stockton, V Sreeguru Lakshman, P Malhotra, S Alapati, S Koduri, J Naveed, J Howard. St Helens and Knowsley NHS Trust, Prescot, UK

10.1136/thoraxjnl-2015-207770.380 